\title{
The phylogeography of an alpine leaf beetle: Divergence within Oreina elongata spans several ice ages
}

\author{
Matthias Borer ${ }^{\mathrm{a}}$, Nadir Alvarez ${ }^{\mathrm{b}}$, Sven Buerki ${ }^{\mathrm{c}}$, Nicolas Margraf ${ }^{\mathrm{d}}$, Martine Rahier ${ }^{\mathrm{a}}$, Russell E. Naisbit ${ }^{\mathrm{a}, \mathrm{e}, *}$ \\ a Laboratory of Evolutionary Entomology, Institute of Biology, University of Neuchâtel, Rue Emile-Argand 11, Case Postale 158, 2009 Neuchâtel, Switzerland \\ ${ }^{\mathrm{b}}$ Department of Ecology and Evolution, University of Lausanne, Biophore Building, 1015 Lausanne, Switzerland \\ ${ }^{\mathrm{c}}$ Department of Biodiversity and Conservation, Real Jardin Botanico, CSIC, Plaza de Murillo 2, 28014 Madrid, Spain \\ ${ }^{\mathrm{d}}$ School of Botany and Zoology, Building 116, Daley Rd., Australian National University, Canberra ACT 0200, Australia \\ ${ }^{\mathrm{e}}$ Unit of Ecology and Evolution, Department of Biology, University of Fribourg, Chemin du Musée 10, 1700 Fribourg, Switzerland
}

\begin{abstract}
A B S T R A C T
The genetic landscape of the European flora and fauna was shaped by the ebb and flow of populations with the shifting ice during Quaternary climate cycles. While this has been well demonstrated for lowland species, less is known about high altitude taxa. Here we analyze the phylogeography of the leaf beetle Oreina elongata from 20 populations across the Alps and Apennines. Three mitochondrial and one nuclear region were sequenced in 64 individuals. Within an mtDNA phylogeny, three of seven subspecies are monophyletic. The species is chemically defended and aposematic, with green and blue forms showing geographic variation and unexpected within-population polymorphism. These warning colors show pronounced east-west geographical structure in distribution, but the phylogeography suggests repeated origin and loss. Basal clades come from the central Alps. Ancestors of other clades probably survived across northern Italy and the northern Adriatic, before separation of eastern, southern and western populations and rapid spread through the western Alps. After reviewing calibrated gene-specific substitution rates in the literature, we use partitioned Bayesian coalescent analysis to date our phylogeography. The major clades diverged long before the last glacial maximum, suggesting that O. elongata persisted many glacial cycles within or at the edges of the Alps and Apennines. When analyzing additional barcoding pairwise distances, we find strong evidence to consider $O$. elongata as a species complex rather than a single species.
\end{abstract}

\section{Introduction}

The Quaternary has proved a turbulent time for the flora and fauna of northern Europe. This period of Earth's history, from around 2.6 million years ago, has witnessed alternating glacial and interglacial periods driven by interactions between tectonic and orbital forces (Webb and Bartlein, 1992; Williams et al., 1998; EPICA community members, 2004). The fluctuating climate would have had profound effects on population migration and survival, the results of which are still apparent in the community composition and genetic diversity of recent organisms (Bennett, 1990). During glacial periods, when large areas of northern Europe were covered by the growing ice shelf and permafrost, most lowland species survived in southern refugia in the Iberian, Italian and Balkan Peninsulas (Hewitt, 1996, 2000, 2004; Taberlet et al., 1998). Recolonization of temperate regions was affected by mountain

* Corresponding author at: Laboratory of Evolutionary Entomology, Institute of Biology, University of Neuchâtel, Rue Emile-Argand 11, Case Postale 158, 2009 Neuchâtel, Switzerland. Fax: +413271830 01 .

E-mail address: russell.naisbit@unine.ch (R.E. Naisbit). ranges such as the Pyrenees or the Alps acting as barriers to some species, so that the contributions of different refugia varied in different taxa. For example, all northern European populations of Chorthippus parallelus and Alnus glutinosa emerged from the Balkans, whereas in Erinaceus and Quercus species, western, central and eastern regions were colonized independently from the Iberian, Italian and Balkan refugia, respectively (Hewitt, 1999). This periodic extinction and recolonization shaped the genetic landscape of Europe, determining the large-scale patterns of spatial genetic structure and diversity (Hewitt, 1996, 2001; Gratton et al., 2008; Fussi et al., 2010).

Whilst these patterns have been well documented for many lowland species, much less is known about the influence of ice ages on high altitude animals (Pauls et al., 2006; Schmitt et al., 2006; Haubrich and Schmitt, 2007; Schmitt, 2009). They provide a contrast with the lowland taxa, since the current warm climate represents a period in which their range has probably contracted. Climate cycles may therefore have led currently isolated populations to have come repeatedly into contact during cold periods as their suitable habitat expanded. For the alpine flora, long-term refugia within the Alps and at their northern, southern and eastern 
borders have been proposed on the basis of recent molecular studies (Stehlik et al., 2001; Stehlik, 2002; Schönswetter et al., 2005). Such results have important implications for the community ecology of montane habitats. If many animal and plant species survived in situ this suggests a long period for coevolution and local adaptation, which would not have been available to most of the more recently assembled communities of the northern lowlands.

Here we address the bias towards lowland taxa by presenting the phylogeography of the alpine leaf beetle Oreina elongata (Suffrian, 1851) (Coleoptera: Chrysomelidae). This species is adapted to survival at high altitudes, with isolated populations found across the Alps and Apennines at altitudes of 1200-2500 m above sea level (Margraf et al., 2003, 2007; Röder et al., 2008). Seven allopatric subspecies have been described based on differentiation of male genitalia (the aedeagus) and cuticle microstructure (Ruffo, 1946; Franz, 1949; Daccordi and Ruffo, 1976, 1986). These herbivorous beetles feed on hosts from two tribes of the Asteraceae: when feeding on Cirsium (Cynareae) larvae and adults synthesize cardenolides, whereas individuals feeding on Adenostyles or Senecio (Senecioneae) encounter plant-produced pyrrolizidine alkaloid $\mathrm{N}$ oxides (PAs) that they are able to sequester (Dobler et al., 1996; Hsiao and Pasteels, 1999; Röder et al., 2007; Verdon et al., 2007). This chemical defense is accompanied by what appears to be warning coloration in bright metallic patterns, with blue, green and mixed populations known. Color pattern does not covary with the type of defense, and the within-population polymorphism is unexpected, because learning by predators would be expected to generate positive frequency-dependent selection and lead to monomorphism (Mallet and Joron, 1999).

In the present study we analyzed the genetic structure of 20 populations of $O$. elongata from across the whole species distribu- tion. Sequencing of regions of three mitochondrial genes and one nuclear gene was used to answer the following questions:

1. Did O. elongata, as a representative of the high altitude fauna, survive the cold periods of the Quaternary in situ in the Alps and Apennines?

2. What does the phylogeography suggest about the evolution of color pattern in the species?

In order to infer the timescale over which differentiation is likely to have arisen, we make use of an approximate molecular dating method based on a review of published gene-specific mtDNA substitution rates to answer a further question:

3 . Was divergence within 0 . elongata a product of the last glacial cycle or is the differentiation more ancient?

\section{Materials and methods}

\subsection{Sampling}

Between 2001 and 2007, O. elongata were collected from 20 populations covering the whole distribution (Alps and Apennines), including most of the sites where the species is known to exist, and all of the seven described subspecies (Ruffo, 1946; Franz, 1949; Daccordi and Ruffo, 1976, 1986; Kippenberg, 1994) (Fig. 1 and Table 1). Samples were preserved in pure ethanol and stored at $-20^{\circ} \mathrm{C}$, apart from the individuals from GLE that were dried specimens from a collection. For most populations, three individuals were chosen for the phylogeographic analysis, using only males to be sure of accurate identification based on genitalia (except for PDC, the holotype location for O. elongata zoiai, for which only

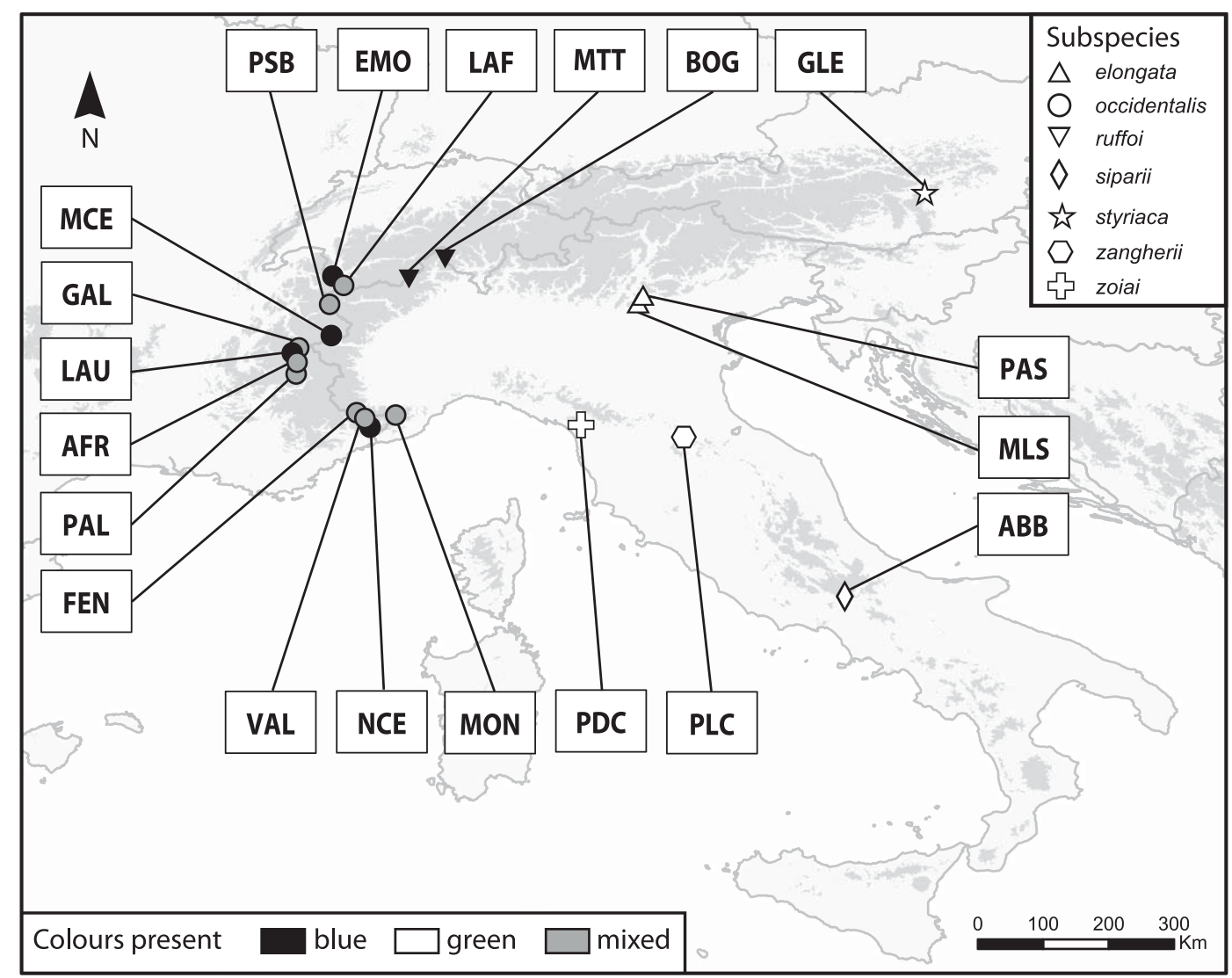

Fig. 1. Distribution of the 20 sampled populations of 0 . elongata in Italy and neighboring countries, showing their subspecies (symbols) and color morphs present (shading). Topographic shading in the Alps and Apennines shows altitudes above $1000 \mathrm{~m}$. 
Table 1

Sampled populations of Oreina elongata with their geographical coordinates, subspecies, number of treated individuals and year of collection.

\begin{tabular}{|c|c|c|c|c|c|c|}
\hline Code & Population & Altitude (m a.s.l.) & Geographical coordinates & Subspecies & Sample size & Year \\
\hline LAF & La Fouly $(\mathrm{CH})$ & 2184 & $45^{\circ} 56^{\prime} \mathrm{N}, 07^{\circ} 04^{\prime} \mathrm{E}$ & occidentalis & 3 & 2006 \\
\hline EMO & Lac Emosson $(\mathrm{CH})$ & 1970 & $46^{\circ} 03^{\prime} \mathrm{N}, 06^{\circ} 55^{\prime} \mathrm{E}$ & occidentalis & 3 & 2007 \\
\hline PSB & Col du Petit St. Bernard (F) & 2188 & $45^{\circ} 40^{\prime} \mathrm{N}, 06^{\circ} 52^{\prime} \mathrm{E}$ & occidentalis & 3 & 2001 \\
\hline MCE & Mont Cenis (F) & 2085 & $45^{\circ} 15^{\prime} \mathrm{N}, 06^{\circ} 54^{\prime} \mathrm{E}$ & occidentalis & 6 & 2005 \\
\hline GAL & Col du Galibier (F) & 1999 & $45^{\circ} 05^{\prime} \mathrm{N}, 06^{\circ} 26^{\prime} \mathrm{E}$ & occidentalis & 3 & 2001 \\
\hline LAU & Col du Lautaret (F) & 1811 & $45^{\circ} 00^{\prime} \mathrm{N}, 06^{\circ} 22^{\prime} \mathrm{E}$ & occidentalis & 3 & 2001 \\
\hline AFR & Ailefroide (F) & 1800 & $44^{\circ} 53^{\prime} \mathrm{N}, 06^{\circ} 26^{\prime} \mathrm{E}$ & occidentalis & 4 & 2001 \\
\hline PAL & Lac Palluel (F) & 2479 & $44^{\circ} 43^{\prime} \mathrm{N}, 06^{\circ} 24^{\prime} \mathrm{E}$ & occidentalis & 3 & 2001 \\
\hline FEN & Col de Fenestre $(\mathrm{F})$ & 2470 & $44^{\circ} 06^{\prime} \mathrm{N}, 07^{\circ} 21^{\prime} \mathrm{E}$ & occidentalis & 3 & 2007 \\
\hline VAL & Terme di Valdieri (I) & 2340 & $44^{\circ} 12^{\prime} \mathrm{N}, 07^{\circ} 15^{\prime} \mathrm{E}$ & occidentalis & 3 & 2001 \\
\hline NCE & L'Authion (F) & 2080 & $44^{\circ} 00^{\prime} \mathrm{N}, 07^{\circ} 26^{\prime} \mathrm{E}$ & occidentalis & 3 & 2001 \\
\hline MON & Monte Mongioie (I) & 1920 & $44^{\circ} 10^{\prime} \mathrm{N}, 07^{\circ} 47^{\prime} \mathrm{E}$ & occidentalis & 3 & 2001 \\
\hline PDC & Pania della Croce (I) & 1718 & $44^{\circ} 02^{\prime} \mathrm{N}, 10^{\circ} 19^{\prime} \mathrm{E}$ & zoiai & 3 & 2007 \\
\hline PLC & Passo la Calla (I) & 1260 & $43^{\circ} 51^{\prime} \mathrm{N}, 11^{\circ} 44^{\prime} \mathrm{E}$ & zangherii & 3 & 2007 \\
\hline ABB & Pizzone (I) & - & $41^{\circ} 41^{\prime} \mathrm{N}, 13^{\circ} 57^{\prime} \mathrm{E}$ & siparii & 3 & 2001 \\
\hline MLS & Giazza (I) & 1510 & $45^{\circ} 41^{\prime} \mathrm{N}, 11^{\circ} 06^{\prime} \mathrm{E}$ & elongata & 3 & 2001 \\
\hline PAS & Monte Pasubio (I) & 2110 & $45^{\circ} 47^{\prime} \mathrm{N}, 11^{\circ} 10^{\prime} \mathrm{E}$ & elongata & 2 & 2001 \\
\hline GLE & Glein (A) & 1570 & $47^{\circ} 13^{\prime} \mathrm{N}, 15^{\circ} 03^{\prime} \mathrm{E}$ & styriaca & 4 & 2004 \\
\hline BOG & Bosco Gurin $(\mathrm{CH})$ & 1835 & $46^{\circ} 18^{\prime} \mathrm{N}, 08^{\circ} 27^{\prime} \mathrm{E}$ & ruffoi & 3 & 2001 \\
\hline MTT & Mattmark $(\mathrm{CH})$ & 2239 & $46^{\circ} 01^{\prime} \mathrm{N}, 07^{\circ} 58^{\prime} \mathrm{E}$ & ruffoi & 3 & 2001 \\
\hline
\end{tabular}

A, Austria; CH, Switzerland; F, France; I, Italy; $m$ a.s.l., metres above sea level.

larvae could be obtained). Trees were rooted using the three most closely related species (Hsiao and Pasteels, 1999): Oreina virgulata, Oreina cacaliae and Oreina speciosissima.

\subsection{Molecular methods}

Total genomic DNA was extracted from four legs of each individual using the DNeasy Tissue Kit (Qiagen, Hilden, Germany). Three regions of mtDNA and one nuclear region were amplified using universal insect primers: a fragment of $16 \mathrm{~S}$ ribosomal RNA [modLR-J12887 (5'-CACCGGTTTGAACTCAGATC-3') with LR-N-13398 (Simon et al., 1994)]; cytochrome oxydase subunit I (COI) [C1-J-1751 with C1-N-2191 (Simon et al., 1994)]; cytochrome oxidase subunit II (COII) [modTL2-J-3037 with modC2-N-3661 (Mardulyn et al., 1997)]; and part of the nuclear region ITS2 [ITS3 with ITS4 (Gomez-Zurita and Vogler, 2003)]. Fragments were amplified using a standard $30 \mu \mathrm{l} \mathrm{PCR} \mathrm{mix} \mathrm{including:} 3 \mu \mathrm{l}$ of extracted DNA, $3 \mu \mathrm{l}$ of $10 \times$ PCR buffer (Promega, Madison, USA), $3 \mu \mathrm{l}$ of $\mathrm{MgCl}_{2}$ solution ( $25 \mathrm{mM}), 3 \mu \mathrm{l}$ of dNTPs $(1.5 \mathrm{mM}), 0.5 \mu \mathrm{l}$ of forward and reverse primer (Microsynth, Balgach, Switzerland), $0.3 \mu$ l of Taq DNA polymerase (Promega, Madison, USA), all made up to a final volume of $30 \mu \mathrm{l}$ with purified MilliQ water. The PCR were run in a Biometra TGradient thermocycler (Biometra, Goettingen, Germany) using the following programs: for $16 \mathrm{~S}$ and COI, initial denaturation for $1.5 \mathrm{~min}$ at $93{ }^{\circ} \mathrm{C}, 36$ cycles $\left(35 \mathrm{~s}\right.$ at $93{ }^{\circ} \mathrm{C}, 1 \mathrm{~min}$ at $45^{\circ} \mathrm{C}, 1.5 \mathrm{~min}$ at $72{ }^{\circ} \mathrm{C}$ ), then final elongation of $8 \mathrm{~min}$ at $72^{\circ} \mathrm{C}$; for COII, initial denaturation of $1.5 \mathrm{~min}$ at $93{ }^{\circ} \mathrm{C}, 36$ cycles $\left(35 \mathrm{~s}\right.$ at $93{ }^{\circ} \mathrm{C}, 1 \mathrm{~min}$ at $53{ }^{\circ} \mathrm{C}, 2 \mathrm{~min}$ at $72{ }^{\circ} \mathrm{C}$ ), then final elongation of $8 \mathrm{~min}$ at $72{ }^{\circ} \mathrm{C}$; for ITS2, initial denaturation of $1.5 \mathrm{~min}$ at $93^{\circ} \mathrm{C}, 36$ cycles $\left(35 \mathrm{~s}\right.$ at $93^{\circ} \mathrm{C}, 1 \mathrm{~min}$ at $48^{\circ} \mathrm{C}$, $1 \mathrm{~min}$ at $72{ }^{\circ} \mathrm{C}$ ), then final elongation of $8 \mathrm{~min}$ at $72^{\circ} \mathrm{C}$. The amplified products were purified using the QIAquick PCR Purification Kit (Qiagen, Hilden, Germany) following the manufacturer's specifications. Sequencing by Macrogen Inc. (Seoul, South Korea) was carried out with both forward and reverse primers under BigDye ${ }^{\mathrm{TM}}$ terminator cycling conditions, purifying the products using ethanol precipitation and running them using an Automatic Sequencer 3730xl (Applied Biosystems, Foster City, USA).

\subsection{Sequence alignment}

Sequences (forward and reverse) were assembled and manually corrected using the software Chromas Pro version 1.34 (Technelysium, Helensvale, Australia). The protein coding nucleotide se- quences of $\mathrm{COI}$ and $\mathrm{COII}$ were checked for reading frame errors and termination codons in MeGA 4 (Tamura et al., 2007). Alignment was carried out using ClustalW Multiple Alignment (Thompson et al., 1994) within the software BioEdit version 7.0.5.3, followed by minor manual correction.

\subsection{Phylogenetic analysis and divergence time estimation}

Phylogenetic relationships within 0 . elongata (including outgroups) were investigated based on Bayesian inference (see below for more details), and maximum parsimony (MP). The MP analysis was performed using PAUP* version 4.0b10 (Swofford, 2002) under the heuristic search option (tree-bisection-reconnection, branch swapping, random sequence addition, MaxTrees $=500$ ) with 1000 random addition replicates.

A partitioned coalescent Bayesian analysis was performed with BEAST 1.4.7 (Drummond and Rambaut, 2007) on the whole mtDNA dataset with the three regions represented as separate partitions (with specific rates of substitutions; see below) in the analysis and best-fit models as estimated by MrModeltest 2.3 (Nylander, 2004). Two independent runs of $60 \times 10^{6}$ generations were performed, sampling one tree every 1000 generations. Due to the lack of fossils for Oreina beetles, direct calibration of the tree topologies was not possible. Instead, branch lengths and node ages in the BEAST analysis were estimated by applying a gene-specific mtDNA substitution rate based on a review of diverse arthropod taxa (Table 2). Average pairwise divergence rates were considered as follows: $1.73 \% \mathrm{My}^{-1}$ for $\mathrm{COI}, 1.38 \% \mathrm{My}^{-1}$ for COII and $0.61 \% \mathrm{My}^{-1}$ for 165 . Based on these values, a relaxed clock with log-normal branch length distribution was used and a Yule speciation model was applied to model population size through time (other prior parameters were set as default; Drummond et al., 2006). For each parameter, convergence of the independent runs was confirmed by the examination of their respective distributions in TRACER 1.4 (Rambaut and Drummond, 2007). After removing a burn-in period in each run, 95\% divergence time confidence intervals were plotted on a majority-rule consensus tree (reconstructed using PAUP*; Swofford, 2002) using TreeAnnotator (Drummond and Rambaut, 2007).

\subsection{Pairwise K-2P distances}

To evaluate lineage divergence in light of the phylogenetic species concept (de Queiroz and Donoghue, 1988), pairwise 
Table 2

Published substitution rates (pairwise divergence per million years) of three mtDNA gene regions for arthropods.

\begin{tabular}{|c|c|c|c|c|}
\hline $\begin{array}{l}\text { Gene } \\
\text { region }\end{array}$ & Taxon & $\begin{array}{l}\text { Substitution } \\
\text { rate }\left(\% \mathrm{My}^{-1}\right)\end{array}$ & Calibration (fossil or biogeographic) & Reference \\
\hline COI & Alpheus (Decapoda: Alpheidae) & 1.40 & Uplift Isthmus of Panama (3 Mya) & Knowlton and Weigt (1998) \\
\hline COI & Sesarma/Sesarmoides (Decapoda: Sesarmidae/Grapsidae) & 1.66 & Uplift Isthmus of Panama (3.1 Mya) & Schubart et al. (1998) \\
\hline $\mathrm{COI}$ & $\begin{array}{l}\text { Ovobathysciola/Patriziella/Speonomus (Coleoptera: } \\
\text { Cholevidae) }\end{array}$ & 2.50 & $\begin{array}{l}\text { Corsica-Sardinia plate separation } \\
\text { (29 Mya) }\end{array}$ & $\begin{array}{l}\text { Caccone and Sbordoni } \\
(2001)\end{array}$ \\
\hline COI & Tetraopes (Coleoptera: Cerambycidae) & 1.50 & Origin of habitats (1-20 Mya) & Farrell (2001) \\
\hline COI & Plateumaris (Coleoptera: Chrysomelidae) & 1.60 & Fossils and biogeography (0.5-10 Mya) & Sota and Hayashi (2007) \\
\hline $16 S$ & Sesarma/Sesarmoides (Decapoda: Sesarmidae/Grapsidae) & 0.65 & Uplift Isthmus of Panama (3.1 Mya) & Schubart et al. (1998) \\
\hline $16 S$ & Petrolisthes/Pachycheles (Decapoda: Porcellanidae) & 0.53 & Uplift Isthmus of Panama (3 Mya) & Stillman and Reeb (2001) \\
\hline $16 S$ & Timarcha (Coleoptera: Chrysomelidae) & 0.45 & Opening of Gibraltar strait (5.3 Mya) & Gomez-Zurita et al. (2000) \\
\hline $16 S$ & Iurus (Scorpiones: Iuridae) & 0.79 & $\begin{array}{l}\text { Separation Crete-Peloponnisos } \\
\text { ( } 5.33 \text { Mya) }\end{array}$ & Parmakelis et al. (2006) \\
\hline COII & Timarcha (Coleoptera: Chrysomelidae) & 0.76 & Opening of Gibraltar strait (5.3 Mya) & Gomez-Zurita et al. (2000) \\
\hline COII & New Zealand cicadas (Hemiptera: Cicadidae) & 2.00 & Geological calibrations (9.3 Mya) & Arensburger et al. (2004) \\
\hline
\end{tabular}

Kimura-2P distances were calculated among specimens based on the $\mathrm{COI}$ dataset using the R package APE following Wiemers and Fiedler (2007) and Buerki et al. (2009). The COI region has proven to be a useful barcoding region for animals (Hebert et al., 2004) and might consequently provide valuable information to define taxa circumscription within the 0 . elongata complex.

\subsection{Color pattern evolution}

To track the evolution of color within O. elongata (i.e., based on the distribution of blue and green morphs), ancestral unordered parsimony reconstruction was performed on the majority-rule consensus tree from BEAST using "trace character history" implemented in MESQUITE, with the accelerated transformation optimization (ACCTRAN) parameter (Maddison and Maddison, 2009).

\section{Results}

\subsection{Sequence dataset}

Six outgroup and 64 ingroup specimens representing all seven described subspecies were collected from the 20 populations and amplified for the three mtDNA and the nuclear ITS2 region. Sequences are available at GenBank under Accession Nos. GQ220057-GQ220295.

When parsed through PAUP* (Swofford, 2002) only three polymorphic sites (in $589 \mathrm{bp}$ ) were identified at the ingroup level within the ITS2 region (amplification was successful for all specimens except four individuals from GLE). Two of those sites were restricted to one clade of the mtDNA phylogeny (the 0 . e. siparii clade, see below), whereas the remaining site corresponded to a split between taxa from eastern and western regions (separated by a line running to the west of MTT and FEN, Fig. 1). Based on this low level of polymorphism, the ITS2 region was not taken into consideration in the following analyses.

The concatenated mtDNA matrix included $1616 \mathrm{bp}$ (including outgroups): $544 \mathrm{bp}$ for $16 \mathrm{~S}$ (nine parsimony-informative [pi] sites among nine polymorphic sites in the ingroup), $397 \mathrm{bp}$ for partial COI (43 pi sites among 47 polymorphic sites in the ingroup) and 675 bp for partial COII ( 13 pi sites among 25 polymorphic sites in the ingroup). The best-fit substitution models and parameter values suggested by MrModeltest (Nylander, 2004) are given in Table 3. Amplification failed in a few cases (for COI, single individuals from VAL, LAF, MTT, and three from PAS; for COII, two from PAS and AFR, and three from BOG, MTT, MLS, GLE and PDC; for 165 all amplifications were successful). This missing data does not seem to have adversely affected the results, for these populations have not been pulled together in the phylogenetic analyses, nor do individuals
Table 3

Best supported models of molecular evolution and estimated parameter values for the analyzed genes.

\begin{tabular}{llllllll}
\hline \multirow{2}{*}{ Gene region } & Model & \multicolumn{7}{c}{ Nucleotide frequencies } \\
\cline { 3 - 7 } & & $\mathrm{A}$ & $\mathrm{T}$ & $\mathrm{C}$ & $\mathrm{G}$ & $\alpha$ & $\mathrm{Tr} / \mathrm{Tv}$ \\
\hline 16S & $\mathrm{HKY}$ & 0.40 & 0.36 & 0.15 & 0.09 & - & 3.517 \\
COI & $\mathrm{HKY}+\mathrm{G}$ & 0.28 & 0.35 & 0.20 & 0.17 & 0.0158 & 3.708 \\
COII & $\mathrm{HKY}+\mathrm{G}$ & 0.35 & 0.38 & 0.16 & 0.11 & 0.0996 & 4.330 \\
ITS2 & $\mathrm{JC}$ & 0.26 & 0.28 & 0.22 & 0.24 & - & - \\
\hline
\end{tabular}

$\alpha$ is the shape parameter for the gamma distribution and $\operatorname{Tr} / \operatorname{Tv}$ is the transitiontransversion ratio.

with a locus missing fall away from other members of their population.

\subsection{Phylogenetic analyses and divergence time estimation}

Bayesian inference and MP analyses produced highly congruent topologies (with the same major nodes and branching order) and only the phylogenetic tree obtained with Bayesian inference in BEAST is shown (Fig. 2). The majority-rule consensus tree on which 95\% confidence intervals for nodal ages are represented is based on 35,001 trees from two independent runs in BEAST. The applied burnin period for each run was 25 million generations for the first run and 20 million generations for the second run.

Based on the average pairwise substitution rates for each marker, the analysis suggested that all the major clades within 0 . elongata were formed long before the last glacial period (with divergence spanning the last million years; Fig. 2). All basal nodes in this tree have very high support except one, with a Bayesian posterior probability (hereafter BPP) of 0.66 (clade encompassing subclades Vb, Vc and Vd; Fig. 2). Three of the subspecies are monophyletic (O. e. styriaca, O. e. siparii and O. e. zangherii) while the others are paraphyletic or polyphyletic. The most basal lineage contains individuals distributed in the central Alps (clade encompassing clades I and II; BPP: 0.99): clade I (BPP: 1.00) is composed of one population of $O$. e. elongata, whereas the other $O$. e. elongata population together with O. e. ruffoi form clade II (BPP: 0.84) (Figs. 1 and 2). The eastern Alpine population of O. e. styriaca (BPP: 1.00; clade III) and the central Apennines population of 0 . e. siparii (BPP: 1.00; clade IV) then split off as well-defined clades. Finally, the subspecies $O$. e. occidentalis (subclades $\mathrm{Va}$ and $\mathrm{Vd}$, both distributed in the western Alps) is paraphyletic with respect to O. e. zoiai and $O$. e. zangherii (subclades $\mathrm{Vb}$ and $\mathrm{Vc}$, respectively, both occurring in the northern Apennines). However, given the weak support (BPP: 0.66 ) of the node at the base of subclades $\mathrm{Vb}, \mathrm{Vc}$ and $\mathrm{Vd}$, one could also consider a trichotomy involving two 0 . e. occidentalis clades and 0 . e. zangherii with 0 . e. zoiai. 
(a)

(a)

(b)

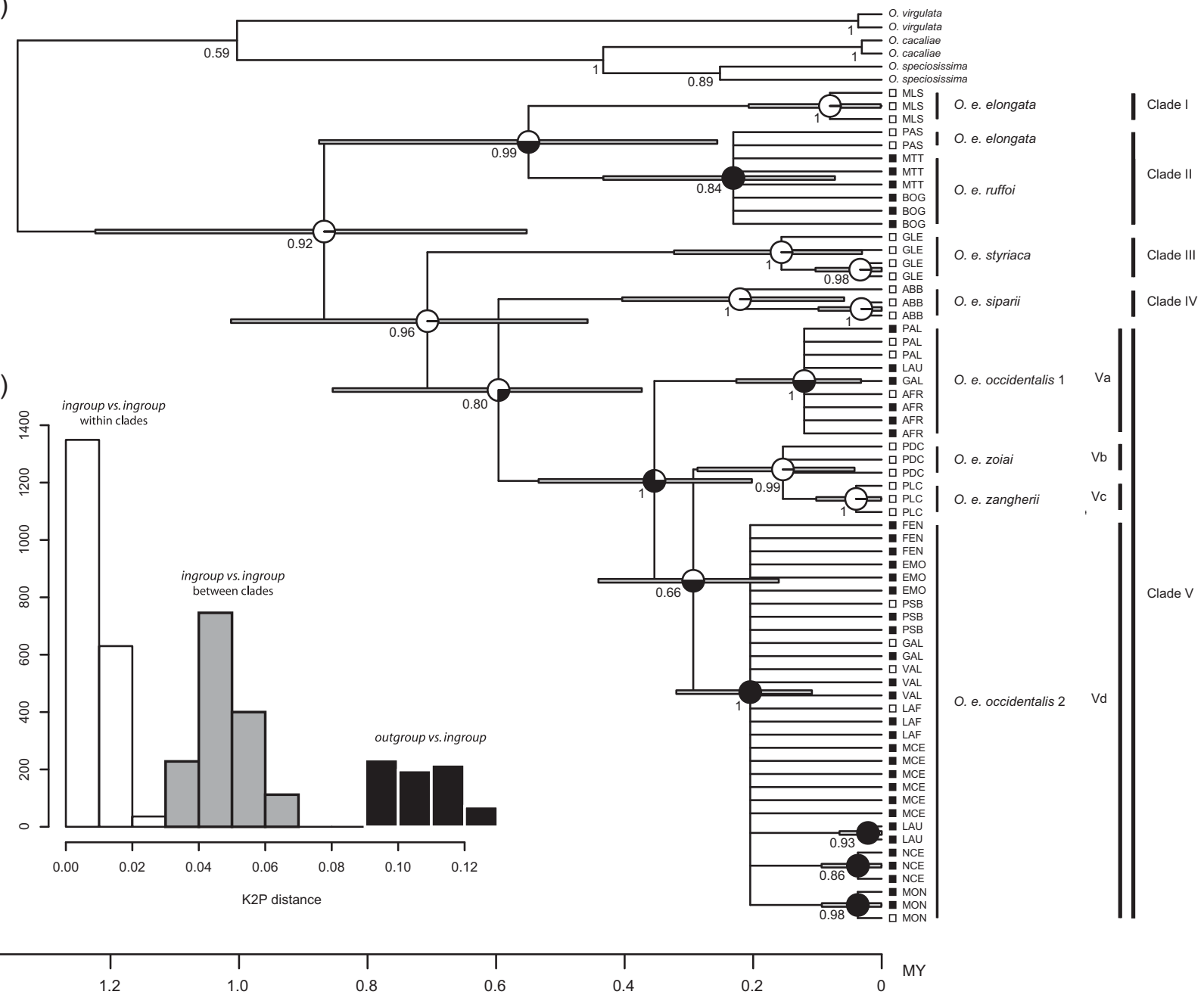

Fig. 2. (a) Majority-rule consensus tree from the MCMC stationary distribution of the partitioned coalescent Bayesian divergence time analysis, with median values and $95 \%$ confidence intervals for nodal ages. Pie-charts represent ancestral character evolution of color patterns reconstructed using the parsimony criterion in MESQUITE (blue morphs shown in black and green morphs in white). The color patterns of individuals are indicated by the squares. Values at the nodes are Bayesian posterior probabilities. Please see Fig. 1 and Table 1 for population codes. (b) Frequency distribution of intra-specific (both within and among clades) and inter-specific genetic divergence in Oreina. Four thousand and ninety-six intra-specific comparisons within O. elongata and 384 inter-specific pairs between 0 . elongata and outgroup taxa were calculated using Kimura's two parameter (K-2P) model.

\subsection{Pairwise $\mathrm{K}-2 \mathrm{P}$ distances}

The pairwise-distance histogram is multi-modal with three major modes (Fig. 2b): the first mode (distributed between zero and 0.03; in white on Fig. 2b) encompasses within-clade distances; the second mode (distributed between 0.03 and 0.07 ; in grey) includes only among-clade distances; the third major mode (distributed between 0.09 and 0.14 ; in black) comprises inter-specific distances including outgroup taxa.

\subsection{Color pattern evolution}

Despite the fact that there is strong geographical structure in the distribution of color variation (with green populations in the eastern part of the species range, and with blue and mixed populations in the west; Fig. 1), the pattern is less clear when mapped onto the phylogeny (Fig. 2). Blue and green morphs are present in the basal group (consisting of both $O$. e. ruffoi and O. e. elongata specimens; clade II), as well as in the two late-diverging clades comprising $O$. e. occidentalis (subclades $\mathrm{Va}$ and $\mathrm{Vd}$ ). All other clades include only green morphs.

\section{Discussion}

Microsatellite data suggest very strong genetic differentiation of populations within 0 . elongata (with an overall $F_{\mathrm{ST}}$ of 0.381 and high pairwise values everywhere) and hence little migration (Margraf et al., 2007). This high level of isolation is confirmed here by the clustering of individuals from the same populations in the phylogeny and by the differentiation of the nuclear locus in 0. e. siparii. Furthermore, the relatively low proportion of polymorphic sites for $16 \mathrm{~S}(1.65 \%)$ and COII (1.93\%) is typical for this taxonomic (intra-specific level) and geographic scale (spanning $800 \mathrm{~km}$ in north-south and east-west directions) (Simon et al., 1994; Wiemers and Fiedler, 2007). However, the high level of polymorphism within the COI region widely used for animal barcoding (11.33\%) and the bi-modal distribution in the $\mathrm{K}-2 \mathrm{P}$ distances at the intraspecific level (with inter-clades distances higher than 0.03) challenges the current species circumscription of 0 . elongata. Expectations from the phylogenetic species concept applied to $\mathrm{COI}$ (Wiemers and Fiedler, 2007) would suggest the split of these five clades into different species rather than subspecies, and hereafter, we favor the concept of a species complex when referring to $O$. elongata. 
Within the 0 . elongata complex, the analyses strongly support the monophyly of three of the seven described subspecies: 0 . e. styriaca (clade III); O. e. siparii (clade IV); and O. e. zangherii (subclade Vc) (Fig. 2). The subspecies O. e. elongata and 0 . e. ruffoi are not monophyletic, while $O$. e. occidentalis is paraphyletic with respect to O. e. zoiai and O. e. zangherii, and O. e. zoiai is paraphyletic with respect to 0 . e. zangherii (Fig. 2).

In light of the unexpectedly high level of polymorphism at COI and the fact that four subspecies are not monophyletic, the taxon circumscription within 0 . elongata should be reviewed by increasing the sampling within populations and investigating additional morphological characters (e.g., the male genitalia and its inner structure). According to the present results, we would favor a solution encompassing five species, corresponding to the five defined clades (Fig. 2).

\subsection{What does the phylogeography suggest about the evolution of color pattern in 0 . elongata?}

The distribution of color pattern variation shows strong geographic structure, with green populations in the eastern Alps and Apennines, blue in southern Switzerland, and both blue and mixed populations scattered throughout the western Alps. However, this would be misleading if taken as a marker of large-scale phylogeographic structure, as shown by comparison with the mtDNA phylogenetic hypothesis. The three outgroup taxa are known to be polymorphic (Kippenberg, 1994), and both green and blue specimens are found in O. elongata clades II, Va and Vd. Nonetheless, all other clades including the putative most recent common ancestor (according to the MESQUITE analysis; Fig. 2) contain only green individuals, suggesting at least two or three independent origins of blue morphs as well as their loss in some populations.

Seven populations (AFR, GAL, LAF, MON, PAL, PSB, VAL) harbor the two morphs. This is unexpected because purifying selection by predators should lead to the loss of this diversity, and because population size is typically small, genetic drift would reinforce this effect. Two potential explanations for within-population polymorphism can be excluded, for it is clear that the two color morphs do not represent coexisting distinct species or subspecies, and neither is there a pattern that would suggest that polymorphism is maintained by current dispersal from monomorphic source populations. The evolutionary forces that maintain this unexpected color polymorphism in a chemically defended species therefore remain to be elucidated.

4.2. Did O. elongata, as a representative of the high altitude fauna, survive the cold periods of the Quaternary in situ in the Alps and Apennines?

The phylogenetic analysis and molecular clock hypothesis, even if only providing an approximate dating method, show that separation of the major clades in $O$. elongata occurred long before the last glacial maximum. In fact, divergence within the species spanned roughly half of the Quaternary, and the repeated glacial and interglacial periods may have been the engine for this differentiation. In contrast to lowland taxa, these beetles are likely to have occupied a larger area during cold periods, for although they may have been forced to retreat from the highest altitudes by the enlargement of glaciers within the Alps, a greater area of lower habitats would have become available. Despite this, our results suggest that the major lineages remained isolated during these periods. During warm spells like the present they display a reduced distribution, separated into more isolated, higher altitude populations. The general pattern in the phylogeography is that the populations from the central Swiss Alps and northern Italy are basal, with subsequent separation of the eastern, southern (Apennines) and western ex- tremes of the distribution, and finally a second colonization of the Apennines. The basal populations in clades I and II in the Central Alps separate early and must have survived many glacial cycles in isolation from the rest of the species, perhaps in refuges within the Alps. The ancestors of the other clades remained in contact elsewhere, and may have inhabited an expanded range during repeated cold periods south of the Alps across northern Italy and the northern part of the Adriatic (which would have been exposed at such times by falling sea levels). Populations from this region seem to have given rise to the subspecies $O$. e. styriaca in the eastern Alps, and 0 . e. siparii in the central Apennines between 0.7 and 0.6 Mya. The remaining populations may have survived colder periods along the edge of the western Alps. Geographical structuring within subspecies 0 . e. occidentalis (with subclades Va and Vd diverging c. 0.4 Mya) is associated with the north-south orientated Guisane and Durance valleys, with the populations PAL and AFR found to the south and in the north the populations LAU and GAL (both containing individuals from subclades $\mathrm{Va}$ and $\mathrm{Vd}$, suggesting some gene flow). The remaining populations form subclade Vd. Subclades $\mathrm{Vb}$ and $\mathrm{Vc}$ are associated with a second invasion into the Apennines around 0.3 Mya (corresponding to subspecies $O$. e. zoiai and 0 . e. zangherii, respectively).

The structuring within $O$. elongata is very similar to that seen in Alpine plants. The contemporary distributions of alpine populations correspond to the four refugia proposed for alpine plants along the southwestern, southern and eastern edges of the Alps (Schönswetter et al., 2005; Margraf et al., 2007). Peripheral refugia in the southwestern and southern Alps have also been suggested for the mountain ringlet, Erebia epiphron (Schmitt et al., 2006), and the caddisfly, Drusus discolor (Pauls et al., 2006). O. elongata therefore joins the list of high altitude plant and animal species that appear to have survived glacial periods close to their current distribution (Schmitt, 2009). The phylogeography presented here indicates that divergence of the major clades occurred between 1 and 0.3 million years ago, suggesting that $O$. elongata survived the Quaternary within or at the edge of the Alps and Apennines.

\section{Acknowledgments}

We are very grateful to Mauro Daccordi, Stefano Zoia and especially to Horst Kippenberg for very helpful conversations about Oreina populations and for providing specimens, and to Anahi Espindola for helping to produce the distribution map. The work was funded by the Swiss National Science Foundation (Grants 3100-064864.01 and 3100-AO-118031), the NSF National Centre of Competence in Research Plant Survival, and a university doctoral assistantship to Matthias Borer.

\section{References}

Arensburger, P., Buckley, T.R., Simon, C., Moulds, M., Holsinger, K.E., 2004. Biogeography and phylogeny of the New Zealand cicada genera (Hemiptera: Cicadidae) based on nuclear and mitochondrial DNA data. J. Biogeogr. 31, 557569 .

Bennett, K.D., 1990. Milankovitch cycles and their effects on species in ecological and evolutionary time. Paleobiology 16, 11-21.

Buerki, S., Callmander, M.W., Schüpfer, F., Ravokatra, M., Alvarez, N., 2009. Malagasy Dracaena Vand. ex L. (Ruscaceae): an investigation of discrepancies between morphological features and spatial genetic structure at a small evolutionary scale. Plant Syst. Evol. 280, 15-28.

Caccone, A., Sbordoni, V., 2001. Molecular biogeography of cave life: a study using mitochondrial DNA from bathysciine beetles. Evolution 55, 122-130.

Daccordi, M., Ruffo, S., 1976. Le specie appenniniche del genere Oreina. Bollettino del Museo Civico di Storia Naturale di Verona 3, 379-411.

Daccordi, M., Ruffo, S., 1986. Due nuove sottospecie appenniniche di Oreina elongata (Suffrian). Bollettino del Museo Civico di Storia Naturale di Verona 13, 13-18.

de Queiroz, K., Donoghue, M.J., 1988. Phylogenetic systematics and the species problem. Cladistics 4, 317-338.

Dobler, S., Mardulyn, P., Pasteels, J.M., Rowell-Rahier, M., 1996. Host-plant switches and the evolution of chemical defense and life history in the leaf beetle genus Oreina. Evolution 50, 2373-2386. 
Drummond, A.J., Ho, S.Y.W., Phillips, M.J., Rambaut, A., 2006. Relaxed phylogenetics and dating with confidence. PLoS Biol. 4, 699-710.

Drummond, A.J., Rambaut, A., 2007. BEAST: Bayesian evolutionary analysis by sampling trees. BMC Evol. Biol. 7, 214-221.

EPICA community members, 2004. Eight glacial cycles from an Antarctic ice core. Nature 429, 623-628.

Farrell, B.D., 2001. Evolutionary assembly of the milkweed fauna: cytochrome oxidase I and the age of Tetraopes beetles. Mol. Phylogenet. Evol. 18, 467-478.

Franz, H., 1949. Zur Kenntnis der Rassenbildung bei Käfern der ostalpinen Fauna. Zentralblatt für das Gesamtgebiet der Entomologie 3, 3-23.

Fussi, B., Lexer, C., Heinze, B., 2010. Phylogeography of Populus alba (L.) and Populus tremula (L.) in Central Europe: secondary contact and hybridisation during recolonisation from disconnected refugia. Tree Genet. Genomes 6, 439-450.

Gomez-Zurita, J., Juan, C., Petitpierre, E., 2000. The evolutionary history of the genus Timarcha (Coleoptera, Chrysomelidae) inferred from mitochondrial COII gene and partial 16S rDNA sequences. Mol. Phylogenet. Evol. 14, 304-317.

Gomez-Zurita, J., Vogler, A.P., 2003. Incongruent nuclear and mitochondrial phylogeographic patterns in the Timarcha goettingensis species complex (Coleoptera, Chrysomelidae). J. Evol. Biol. 16, 833-843.

Gratton, P., Konopinski, K., Sbordoni, V., 2008. Pleistocene evolutionary history of the Clouded Apollo (Parnassius mnemosyne): genetic signatures of climate cycles and a 'time-dependent' mitochondrial substitution rate. Mol. Ecol. 17 , 4248-4262.

Haubrich, K., Schmitt, T., 2007. Cryptic differentiation in alpine-endemic, highaltitude butterflies reveals down-slope glacial refugia. Mol. Ecol. 16, 36433658

Hebert, P.D.N., Penton, E.H., Burns, J.M., Janzen, D.H., Hallwachs, W., 2004. Ten species in one: DNA barcoding reveals cryptic species in the neotropical skipper butterfly Astraptes fulgerator. Proc. Natl. Acad. Sci. 101, 14812-14817.

Hewitt, G.M., 1996. Some genetic consequences of ice ages, and their role in divergence and speciation. Biol. J. Linn. Soc. 48, 247-276.

Hewitt, G.M., 1999. Post-glacial re-colonization of European biota. Biol. J. Linn. Soc. 68, 87-112.

Hewitt, G.M., 2000. The genetic legacy of the Quaternary ice ages. Nature 405, 907913.

Hewitt, G.M., 2001. Speciation, hybrid zones and phylogeography - or seeing genes in space and time. Mol. Ecol. 10, 537-549.

Hewitt, G.M., 2004. Genetic consequences of climatic oscillations in the Quaternary. Philos. Trans. R. Soc. B 359, 183-195.

Hsiao, T.H., Pasteels, J.M., 1999. Evolution of host-plant affiliation and chemica defense in Chrysolina-Oreina leaf beetles as revealed by mtDNA phylogenies. In: Cox, M.L. (Ed.), Advances in Chrysomelidae Biology 1. Backhuys Publishers, Leiden, The Netherlands, pp. 321-342.

Kippenberg, H., 1994. 88. Familie Chrysomelidae. In: Lohse, G.A., Lucht, W. (Eds.), Die Käfer Mitteleuropas, 3. Supplement band. Goecke \& Evers, Krefeld, Germany, pp. 65-83.

Knowlton, N., Weigt, L.A., 1998. New dates and new rates for divergence across the Isthmus of Panama. Proc. R. Soc. B 265, 2257-2263.

Maddison, W.P., Maddison, D.R., 2009. Mesquite: a modular system for evolutionary analysis. Version 2.71. http://mesquiteproject.org.

Mallet, J., Joron, M., 1999. Evolution of diversity in warning color and mimicry: polymorphisms, shifting balance, and speciation. Annu. Rev. Ecol. Syst. 30, $201-$ 233.

Mardulyn, P., Milinkovitch, M.C., Pasteels, J.M., 1997. Phylogenetic analyses of DNA and allozyme data suggest that Gonioctena leaf beetles (Coleoptera; Chrysomelidae) experienced convergent evolution in their history of hostplant family shifts. Syst. Biol. 46, 722-747.

Margraf, N., Gotthard, K., Rahier, M., 2003. The growth strategy of an alpine beetle: maximization or individual growth adjustment in relation to seasonal time horizons? Funct. Ecol. 17, 605-610.

Margraf, N., Verdon, A., Rahier, M., Naisbit, R.E., 2007. Glacial survival and local adaptation in an alpine leaf beetle. Mol. Ecol. 16, 2333-2343.

Nylander, J.A.A., 2004. MrModeltest v2. Program Distributed by the Author. Evolutionary Biology Centre, Uppsala University.
Parmakelis, A., Stathi, I., Spanos, L., Louis, C., Mylonas, M., 2006. Phylogeography of Iurus dufoureius (Brulle, 1832) (Scorpiones, Iuridae). J. Biogeogr. 33, 251-260.

Pauls, S.U., Lumbsch, H.T., Haase, P., 2006. Phylogeography of the montane caddisfly Drusus discolor: evidence for multiple refugia and periglacial survival. Mol. Ecol. $15,2153-2169$

Rambaut, A., Drummond, A.J., 2007. Tracer v1.4. Available from: <http:// beast.bio.ed.ac.uk/Tracer>.

Röder, G., Rahier, M., Naisbit, R.E., 2007. Coping with an antagonist: the impact of a phytopathogenic fungus on the development and behaviour of two species of alpine leaf beetle. Oikos 116, 1514-1523.

Röder, G., Rahier, M., Naisbit, R.E., 2008. Counter-intuitive developmental plasticity induced by host quality. Proc. R. Soc. B $275,879-885$.

Ruffo, S., 1946. Nota su alcune specie italiane dei generi Chrysomela L. e Chrysochloa HOPE. Bollettino dell'Istituto di Entomologia della Università degli Studi di Bologna 15, 171-183.

Schmitt, T., 2009. Biogeographical and evolutionary importance of the European high mountain systems. Front. Zool. 6.

Schmitt, T., Hewitt, G.M., Muller, P., 2006. Disjunct distributions during glacial and interglacial periods in mountain butterflies: Erebia epiphron as an example. J. Evol. Biol. 19, 108-113.

Schönswetter, P., Stehlik, I., Holderegger, R., Tribsch, A., 2005. Molecular evidence for glacial refugia of mountain plants in the European Alps. Mol. Ecol. 14, 35473555.

Schubart, C.D., Diesel, R., Hedges, S.B., 1998. Rapid evolution to terrestrial life in Jamaican crabs. Nature 393, 363-365.

Simon, C., Frati, F., Beckenbach, A., Crespi, B., Liu, H., Flook, P., 1994. Evolution, weighting, and phylogenetic utility of mitochondrial gene-sequences and a compilation of conserved polymerase chain-reaction primers. Ann. Ent. Soc. Am. 87, 651-701.

Sota, T., Hayashi, M., 2007. Comparative historical biogeography of Plateumaris leaf beetles (Coleoptera: Chrysomelidae) in Japan: interplay between fossil and molecular data. J. Biogeogr. 34, 977-993.

Stehlik, I., 2002. Glacial history of the alpine herb Rumex nivalis (Polygonaceae): a comparison of common phylogeographic methods with nested clade analysis. Am. J. Bot. 89, 2007-2016.

Stehlik, I., Schneller, J.J., Bachmann, K., 2001. Resistance or emigration: response of the high-alpine plant Eritrichium nanum (L.) Gaudin to the ice age within the Central Alps. Mol. Ecol. 10, 357-370.

Stillman, J.H., Reeb, C.A., 2001. Molecular phytogeny of eastern Pacific porcelain crabs, genera Petrolisthes and Pachycheles, based on the mtDNA 16S rDNA sequence. Phylogeographic and systematic implications. Mol. Phylogenet. Evol. 19, 236-245.

Swofford, D.L., 2002. PAUP*. Phylogenetic Analysis Using Parsimony (*and Other Methods). Sinauer Associates, Sunderland, Massachusetts.

Taberlet, P., Fumagalli, L., Wust-Saucy, A.G., Cosson, J.F., 1998. Comparative phylogeography and postglacial colonization routes in Europe. Mol. Ecol. 7, 453-464.

Tamura, K., Dudley, J., Nei, M., Kumar, S., 2007. MEGA4: Molecular Evolutionary Genetics Analysis (MEGA) Software Version 4.0. Mol. Biol. Evol. 24, 1596-1599.

Thompson, J.D., Higgins, D.G., Gibson, T.J., 1994. CLUSTAL W: improving the sensitivity of progressive multiple sequence alignment through sequence weighting, position-specific gap penalities and weight matrix choice. Nucleic Acids Res. 22, 4673-4680.

Verdon, A., Margraf, N., Davison, A.C., Rahier, M., Naisbit, R.E., 2007. Conserved oviposition preferences in alpine leaf beetle populations despite host shifts and isolation. Ecol. Entomol. 32, 62-69.

Webb, T., Bartlein, P.J., 1992. Global changes during the last 3 million years: climatic controls and biotic responses. Annu. Rev. Ecol. Syst. 23, 141-173.

Wiemers, M., Fiedler, K., 2007. Does the DNA barcoding gap exist? - a case study in blue butterflies (Lepidoptera: Lycaenidae). Front. Zool. 4.

Williams, M., Dunkerley, D., De Decker, P., Kershaw, P., Chappell, J., 1998 Quaternary Environments. Edward Arnold, London, UK. 